\title{
Meningkatkan Hasil Belajar dan Keaktifan Melalui Game Rangking 1 dengan Materi Umum Bersama Anak Panti Asuhan As-Sohwah
}

\author{
Andri Eka Kusuma Ningrum ${ }^{1}$, Hafifah Ervilda ${ }^{2}$, Afrinaldi ${ }^{3}$, Dion Oktamade ${ }^{4}$, \\ Muhammad Syafik Hidayat ${ }^{5}$, Gilang Fikri Andrizal ${ }^{6}$, Rama Gita Suci ${ }^{7}$ \\ ${ }^{1,4,6,7}$ Fakultas Ekonomi dan Bisnis, Universitas Muhammadiyah Riau \\ ${ }^{2,3,5}$ Fakultas Teknik, Universitas Muhammadiyah Riau \\ email: andrieka017@gmail.com
}

\begin{abstract}
The purpose of holding a rank 1 game is to test improving learning outcomes and the activeness of the children of the As-Shohwah orphanage. This activity 1st rank game was held at the elementary-junior-high school level, the 1st rank was held at the As-Shohwah Orphanage, Simpang Baru Village, Pekanbaru City. Group 11 held a ranking 1 game method by providing training and then giving a competition in the form of general questions. The results of the 1st rank game in children get enthusiastic, increased interest in learning again, lively and active enthusiasm in answering questions in the 1st rank game play.
\end{abstract}

Keywords: Rank 1, Game, Active

\begin{abstract}
Abstrak
Tujuan dari mengadakan game rangking 1 untuk menganalisis peningkatkan hasil belajar dan keaktifan anak-anak panti asuhan As-Shohwah. Game rangking 1 ini diadakan dengan tingkatan SD-SMP-SMA, kegiatan ini diadakan di Panti Asuhan As-Shohwah Kelurahan Simpang Baru, Kota Pekanbaru. Kelompok 11 mengadakan metode permainan rangking 1 dengan memberikan pelatihan dan kemudian memberikan lomba dalam bentuk soal-soal umum. Hasil dari game rangking 1 pada anak-anak mendapatkan antusias, peningkatan minat belajar kembali, semangat yang meriah dan aktif dalam menjawab soal-soal pada permainan game rangking 1 .
\end{abstract}

Kata Kunci: Rangking 1, Permainan, Keaktifan

\section{PENDAHULUAN}

Masa Pandemi COVID-19 sangat berdampak pada dunia pendidikan. Anakanak yang berada di panti asuhan harus segera menyesuaikan diri untuk bisa belajar dengan sistem pembelajaran jarak jauh. Dalam kegiatan pembelajaran sering terlihat dan dirasakan masih banyak anakanak yang kurang aktif dalam mengikuti kegiatan pembelajaran. Guru masih belum mampu membangkitkan semangat dan keaktifan anak-anak dalam mengikuti kegiatan pembelajaran karena tidak dapat mengawasi langsung. Pada sisi lain, hasil belajar anak-anak juga masih kurang memuaskan. Kondisi tersebut dapat terjadi karena salah satu faktornya guru belum kreatif dan inovatif dalam proses pembelajaran kemudian anak-anak yang kurang diawasi guru karena jarak jauh dimana proses pembelajaran dilakukan secara daring atau online. Panti Asuhan As-Shohwah beralamat di Jl. Merpati sakti No. 11C Kelurahan Simpang Baru, Kecamatan Binawidya, Kota Pekanbaru. Berdiri pada tahun 2002, ditandai dengan diterbitkanya surat izin operasional No. 432/411.42/PEMSOS tertanggal 5 Agustus 2002. Panti asuhan ini merupakan sebuah yayasan yang dipelopori oleh $\mathrm{H}$. Mahyuddin Datuk A.A dan seorang 
mahasiswa UIN Suska Riau yang bernama Asep Saepullah.

Dari pengalaman dan pengamatan langsung yang kami temukan di panti asuhan As-Shohwah selama pembelajaran daring/online anak-anak dalam belajar sangat tidak efektif, pada umumnya masih terdapat beberapa masalah yang berhubungan dengan pembelajaran. Beberapa masalah yang dihadapi anakanak dalam pembelajaran, antara lain: (1) kesulitan mengingat suatu konsep/materi pokok pelajaran, (2) kesulitan menjawab soal-soal dari suatu konsep/materi pokok pelajaran yang diberikan, (3) minat belajar yang menurun. Menurut hasil uji kemampuan (UK) pada pembelajaran saat setiap pertemuan terhadap 36 anak-anak panti mulai dari SD-SMP-SMA. Mereka kurang semangat dan aktif dalam belajar terlebih lagi dikarenakan pembelajaran dengan proses online atau daring, dikarenakannya COVID-19.

Berdasarkan uraian di atas, tim pengabdian melakukan kolaborasi dengan kelompok 11 Kuliah Kerja Nyata (KKN) Universitas Muhammadiyah Riau untuk menerapkan model permainan (game) Ranking 1 dalam pembelajaran soal-soal umum dan menuangkannya dalam karya ilmiah dengan judul "Meningkatkan Hasil Belajar dan Keaktifan Melalui Game Rangking 1 dengan Materi Umum Bersama Anak Panti Asuhan As-Sohwah". Pengertian Hakikat Belajar

Menurut [1] Belajar pada hakikatnya adalah proses interaksi terhadap semua situasi yang ada di sekitar individu. Belajar dapat dipandang sebagai proses yang diarahkan kepada tujuan dan proses berbuat melalui berbagai pengalaman. Belajar juga merupakan proses melihat, mengamati, dan memahami sesuatu. Menurut [2] belajar dapat di definisikan sebagai suatu proses di mana suatu organisme berubah perilakunya sebagai akibat pengalaman. Belajar dan mengajar merupakan dua konsep yang tidak dapat dipisahkan satu sama lain. Dua konsep ini menjadi terpadu dalam satu kegiatan di mana terjadi interaksi antara pendidik dengan peserta didik, serta peserta didik dengan peserta didik pada saat pembelajaran berlangsung.

Berdasarkan pengertian para ahli di atas, maka dapat ditarik kesimpulan bahwa belajar adalah suatu aktivitas seseorang yang dilakukan secara sengaja dan sadar untuk memperoleh pengetahuan baru. Sehingga memungkinkan seseorang terjadinya perubahan perilaku yang relatif baik dalam berpikir maupun bertindak.

\section{Pengertian Keaktifan}

Belajar tidak dapat dipaksakan oleh orang lain dan juga tidak dapat dilimpahkan kepada orang lain. Belajar hanya mungkin terjadi apabila anak aktif mengalaminya sendiri. [3] mengemukakan bahwa belajar adalah menyangkut apa yang harus dikerjakan peserta didik untuk dirinya sendiri, maka inisiatif harus datang sendiri. Keterlibatan siswa dalam belajar, membuat anak secara aktif terlibat dalam proses pembelajaran. Partisipasi aktif siswa sangat berpengaruh pada proses perkembangan berpikir, emosi, dan sosial [4].

\section{Pengertian Pembelajaran}

Menurut [5] mengatakan, bahwa pembelajaran adalah proses interaksi peserta didik dengan pendidik dan sumber belajar pada suatu lingkungan belajar. Pembelajaran merupakan bantuan yang diberikan pendidik agar dapat terjadi proses perolehan ilmu dan pengetahuan, penguasaan kemahiran dan tabiat, serta pembentukan sikap dan kepercayaan pada peserta didik. Dengan kata lain, pembelajaran adalah proses untuk membantu peserta didik agar dapat belajar dengan baik. Proses pembelajaran dialami sepanjang hayat seorang manusia serta dapat berlaku di manapun dan kapanpun.

Berdasarkan pengertian menurut para ahli di atas, maka dapat dipahami bahwa pembelajaran adalah proses usaha sadar dari pendidik untuk membuat peserta didik belajar. Salah satu usaha yang 
dapat dilakukan adalah menerapkan metode pembelajaran yang bertujuan mengaktifkan siswa yaitu supaya siswa mau bertanya tentang materi yang sedang dipelajari terlebih dahulu kepada teman sekelompoknya, bersemangat untuk mengerjakan latihan serta mempunyai rasa tanggung jawab dengan tugas dan kelompoknya [6].

\section{Pengertian Hasil Belajar}

Pengertian tentang hasil belajar menurut [7] bahwa "hasil belajar merupakan perubahan perilaku yang meliputi tiga ranah, yaitu ranah kognitif, afektif dan psikomotor. Ranah kognitif meliputi tujuan-tujuan belajar yang berhubungan dengan memanggil kembali pengetahuan dan pengembangan kemampuan intelektual dan keterampilan. Ranah afektif meliputi tujuan-tujuan belajar yang menjelaskan perubahan sikap, minat, nilai-nilai dan pengembangan apresiasi serta penyesuaian. Ranah psikomotor mencakup perubahan perilaku yang menunjukkan bahwa siswa telah mempelajari keterampilan manipulatif fisik tertentu".

\section{METODE PENGABDIAN}

Tim pengabdian mengadakan pengamatan secara langsung pada anakanak serta melakukan wawancara langsung dengan pihak yang bersangkutan dan sejumlah personil yang ada kaitannya dengan pengabdian ini. Metode yang digunakan berupa pelatihan pembelajaran terlebih dahulu dengan pelatihan, diskusi membahas teori-teori dengan membentuk kelompok-kelompok kecil sesuai dengan tingkatan kelas anakanak panti asuhan As-Shohwah. Setelah kelompok kecil terbentuk, dilakukan pembahasan materi dengan mencampurkan permainan agar dapat meningkatkan minat dan keaktifan anak anak. Tahap terakhir dengan mengumpulkan peserta kelompok untuk mengikuti game rangking 1 dengan menjawab soal-soal umum yang sudah dipelajari. Hasil jawaban kemudian diseleksi, dikelompokkan untuk mencari pemenangnya.

Penggunaan metode permainan (game) diharapkan dapat memberikan suatu suasana pembelajaran yang lebih santai dan menyenangkan sehingga dapat menumbuhkan suasana pembelajaran yang interaktif, menumbuhkan semangat dan motivasi belajar anak, menambah dan memperkuat solidaritas sosial, menambah wawasan, dan meningkatkan prestasi belajar pada anak panti asuhan As-Shohwah. Kegiatan permainan (game) Ranking I bertujuan untuk meningkatkan dan sekaligus menguji kemampuan anak, baik kognitif, efektif, maupun psikomotorik. Dari segi kognitif, permainan ini bertujuan menambah dan memperkuat pengetahuan yang telah diperoleh anak. Secara efektif, permainan (game) Ranking I mendidik dan menanamkan kebersamaan dan kolektivitas kehidupan nyata nantinya. Kemudian secara psikomotorik, permainan ini memberikan keterampilan menulis jawaban secara baik dan benar.

Rancangan kegiatan pembelajaran dilakukan dengan mengkaji materi, membuat konsep soal, menyiapkan papan jawaban, membuat kunci jawaban dan skor penilaian. Rancangan kegiatan pembelajaran dengan model permainan (game) Ranking 1 dengan tahapan sebagai berikut:

a. Kegiatan Awal \pm 15 Menit

Sebelum permainan dimulai panitia memperhatikan keadaan lingkungan belajar, menyiapkan alat dan bahan Game Rangking 1, kemudian panitia mengucapkan salam dan meng-absen anak-anak. Panitia menyampaikan tujuan Game Rangking 1, serta menjelaskan bagaimana tata cara pelaksanaan Game Rangking 1.

b. Kegiatan Inti \pm 60 Menit

Panitia membagi beberapa kategori dalam permainan (Game) Rangking 1. Untuk tahap pertama 
tingkat SD-SMP digabung didalam aula Game Rangking 1 dan untuk tahap ke dua dilanjutkan dengan tingkat SMA. Setelah itu panitia yang lain menyusun adik-adik panti asuhan sesuai dengan urutan nomor.

Selanjutnya panitia pembaca soal akan menjelaskan bagaimana cara menjawab pertanyaan Rangking 1 yaitu :

1. Pantia akan membaca kan soal dengan pengulangan sebanyak 3 kali.

2. Setelah panitia selesai membacakan soal, adik-adik boleh menjawab pertanyaan yang sudah diberikan dengan waktu menjawab 5 detik.

3. Setelah waktu 5 detik berakhir peserta mengangkat papan jawaban mereka masingmasing.

4. Untuk tahapan mencari pemenang, 3 orang terakhir dalam permainan akan diberikan soal final untuk mencari siapa pemenang dalam Game Rangking 1. Setelah soal dibacakan Game Rangking 1 pun dimulai. Untuk para adik-adik panti asuhan yang jawabanya atau hasil belajarnya salah maka mereka tereliminasi dalam babak.

c. Kegiatan \pm 15 menit

Untuk dibabak final 3 orang tersisa setiapa tingkatan SD, SMP dan SMA didalam permainan akan dilanjutkan ke babak final untuk mecari siapa pemenang dalam Game Rangking 1.
Tabel 1. Jadwal Kegiatan

\begin{tabular}{|c|c|}
\hline Waktu & Acara \\
\hline \multicolumn{2}{|c|}{ Minggu Pertama } \\
\hline Jum'at & Persiapan Soal \\
\hline Sabtu & $\begin{array}{c}\text { Informasikan Acara } \\
\text { ke pihak panti }\end{array}$ \\
\hline Minggu & $\begin{array}{c}\text { Sosialisasi } \\
\text { Kegiatan dan } \\
\text { perkenalan panitia } \\
\text { dengan anak-anak }\end{array}$ \\
\hline \multicolumn{2}{|c|}{ Minggu Kedua } \\
\hline $\begin{array}{c}\text { Senin, Selasa, } \\
\text { Rabu }\end{array}$ & $\begin{array}{c}\text { Diskusi dan latihan } \\
\text { tentang materi yang } \\
\text { akan dipelajari } \\
\text { (sesuai kurikulum } \\
\text { sekolah) }\end{array}$ \\
\hline Kamis & $\begin{array}{c}\text { Diskusi materi } \\
\text { perkelompok untuk } \\
\text { perlombaan } \\
\text { Rangking } 1\end{array}$ \\
\hline \multicolumn{2}{|c|}{ Minggu Ketiga } \\
\hline \multirow{5}{*}{ Sabtu } & Pembukaan Acara \\
\hline & $\begin{array}{c}\text { Pembacaan Tata } \\
\text { Tertib Acara }\end{array}$ \\
\hline & $\begin{array}{l}\text { Perlombaan } \\
\text { Rangking } 1\end{array}$ \\
\hline & Pembagian Hadiah \\
\hline & Penutup \\
\hline
\end{tabular}

Sebelum itu panitia terlebih dahulu membacakan tata tertib dan tata cara perlombaan rangking 1 yang akan diadakan supaya anak-anak atau peserta tidak bingung pada saat menjawabnya. 


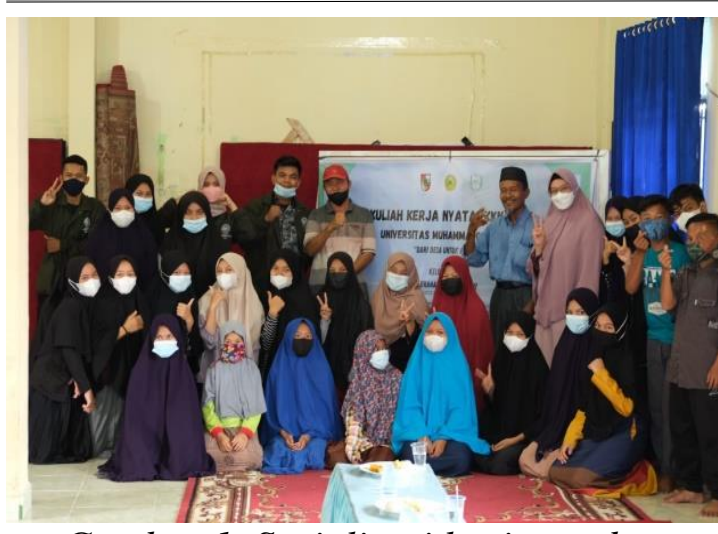

Gambar 1. Sosialisasi kegiatan dan perkenalan panitia

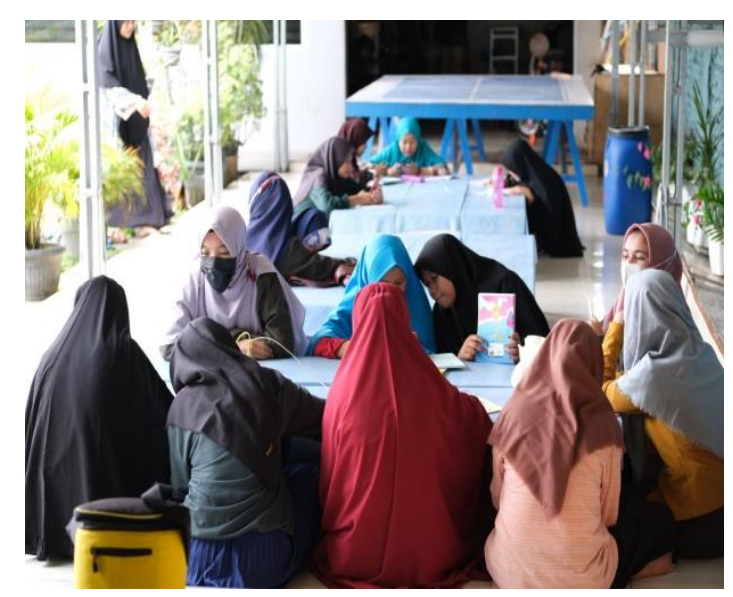

Gambar 2. Diskusi materi

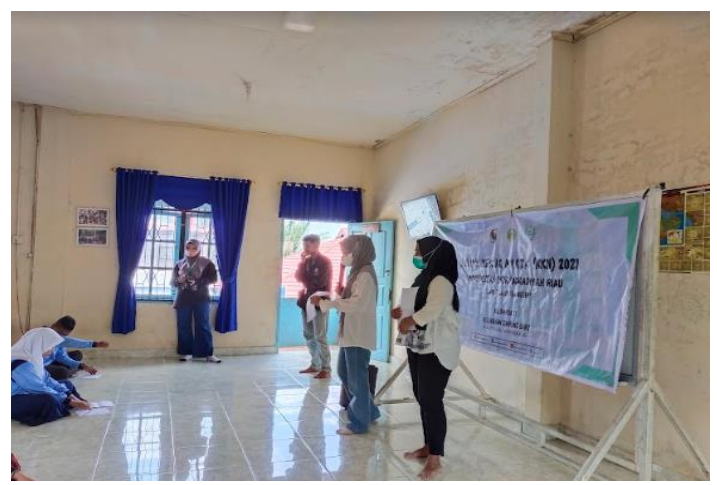

Gambar 3. Panitia membacakan tata tertib

\section{HASIL DAN PEMBAHASAN}

\section{Hasil Belajar Anak-anak Panti Asuhan As-Shohwah}

Berdasarkan beberapa waktu pelatihan yang dilakukan, anak-anak Panti Asuhan lebih aktif dalam belajar sambil bermain game seperti Rangking 1 dibandingkan hanya belajar melalui telepon genggam/ internet saja. Karena pada umumnya guru hanya menjelaskan lewat media handphone saja dikarenakan pandemi Covid-19 berlangsung. Pembelajaran jarak jauh masih dirasa kurang efektif karena anak-anak tidak memahami apa yang dijelaskan guru, anak-anak pun kebanyakan tidak memperhatikan materi yang diberikan oleh guru. Maka selama masa pandemi Covid19 anak-anak merasa bosan dalam proses pembelajaran daring/online dikarenakan guru menjelaskan melewati aplikasi daring saja dengan tidak disertai metode lain yang dapat menarik minat siswa.

Tingkat keaktifan anak-anak panti adalah keadaan dimana anak-anak dalam bekerja secara berkelompok dapat bekerja sama, ada kebersamaan, ada dinamika, dan keaktifan anak-anak berbicara dan bekerja menyelesaikan tugas kelompok. Untuk memantau dan merekam aktifitas anak dalam kelompok tersebut dibantu oleh para mahasiswa KKN yang bertindak selaku kolaborator dalam pengabdian ini. Ada format yang sudah disediakan dan telah disepakati faktor dan skor/nilai untuk menggambarkan tingkat aktifitas siswa dalam kelompok. Maka dari itu Mahasiswa KKN membuat cara bagaimana para anak-anak semangat dan aktif dalam proses pembelajaraan. Mahasiswa KKN Kelompok 11 mengadakan game rangking 1 untuk meningkatkan keaktifan para anak-anak panti asuhan As-Shohwah.

Dari hasil observasi atau pengamatan oleh tim pengabdian dan mahasiswa KKN yang bertindak selaku kolaborator dari kegiatan ini. Hampir seluruh anak-anak semangat dan aktif dalam program kegiatan game rangking 1 jika dibandingkan dari hari pertama kegiatan ini dilaksanakan, dimana tingginya antusias minat bertanya, keingintahuan pemecahan masalah pada materi yang diberikan dan proses pembelajaran pada anak-anak lebih efektif ketimbang belajar dengan proses daring/online. Hal ini juga didukung oleh 
peningkatan kemampuan nalar, daya ingat, mengulang menjelaskan kembali materi apa yang tim pengabdi jelaskan kepada anak-anak dan hasil nilai dari proses pembelajaran pada jawaban pengerjaan soal materi yang diberikan dari hari ke hari hingga perlombaan dari game rangking 1.

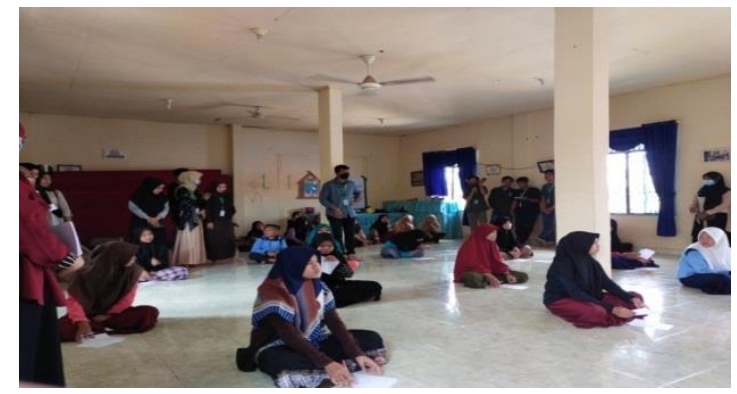

Gambar 4. Proses Pelaksanaan Game Rangking 1

\section{SIMPULAN}

Ada peningkatan hasil belajar anak-anak panti yang positif selama kegiatan pembelajaran materi umum dengan menggunakan model permainan (game) Ranking 1. Keterlibatan siswa dalam belajar, membuat anak secara aktif terlibat dalam proses pembelajaran. Hal ini ditunjukkan hampir seluruh anak-anak semangat dan aktif dalam game rangking 1, tingginya antusias bertanya dan semangatnya mengerjakan soal-soal latihan yang diberikan dengan diselingi permainan. Hasil belajar anak-anak juga meningkat dilihat dari hasil nilai yang diperoleh serta penilaian pemahaman anak-anak dimana pada saat tim pengabdian membimbing anak-anak dalam proses belajar mereka, mereka mampu menangkap atau menjelaskan kembali apa yang tim pengabdi telah jelaskan sebelumnya

\section{UCAPAN TERIMAKASIH}

Proses pembelajaran alangkah lebih efektifnya tidak hanya menyampaikan materi pembelajaran saja namun juga diselingi dengan permainan yang membuat anak-anak tertarik dan semangat mengikuti pembelajaran. Mengajar dengan menggunakan metode dan model pembelajaran yang bervariasi sehingga tidak menimbulkan kebosanan dan kejenuhan pada anak-anak dalam mengikuti pembelajaran walaupun dengan sistem belajar daring, khususnya dengan menggunakan model permainan (game).

\section{DAFTAR PUSTAKA}

\section{[1].}
Rusman.
"Model-Model
Pembelajaran". PT RajaGafondo Persada. 2016.

[2]. Susanto, A. "Teori Belajar \& Pembelajaran di Sekolah Dasar". Prenadamedia Group. 2013.

[3] Rusman. "Belajar dan Pembelajaran Berorientasi standar Proses pendidikan" . Kencana. 2017.

[4] Wibowo, Nugroho. "Upaya Peningkatan Keaktifan Siswa Melalui Pembelajaran Berdasarkan Gaya Belajar Di Smk Negeri 1 Saptosari”. J. Elinvo, vol. 1, no. 2, 2016.

[5]. Suardi, M. "Belajar dan Pembelajaran". Deepublish. 2018.

[6] Rosnah. " Penerapan Metode True Or False Untuk Meningkatkan Hasil Belajar Matematika Siswa Kelas VIII. 7 SMP Negeri 21 Pekanbaru". J. Dinamisia, vol. 2 no. 1, 2018.

[7]. Rusmono. "Strategi pembelajaran Dengan Problem Based Learning Itu Perlu". Ghalia Indonesia. 2017. 